Int. J. Dev. Biol. 54: 495-505 (2010)

doi: $10.1387 / \mathrm{ijdb} .082761 \mathrm{eb}$

\title{
Trophoblast phagocytic program: roles in different placental systems
}

\author{
ESTELA BEVILACOUA*,1, MARA-SANDRA HOSHIDA ${ }^{1}$, ANDREA AMARANTE-PAFFARO², \\ ANDREA ALBIERI-BORGES ${ }^{3}$ and SARA ZAGO GOMES ${ }^{1}$ \\ ${ }^{1}$ University of São Paulo, SP, ${ }^{2}$ Federal University of Alfenas, MG \\ and ${ }^{3}$ State University of Rio de Janeiro, RJ, Brazil
}

\begin{abstract}
Although not belonging to the class of professional phagocytes, in many species trophoblast cells exhibit intense phagocytic activity. The complete range of physiological functions of trophoblast phagocytosis has not yet been fully characterized. Close association between the trophoblast and nutrition was determined many years ago. Hubrecht (1889) when proposing for the first time the name trophoblast to the external layer of the blastocyst, directly established the nutritive significance of this embryonic layer. Indeed, histotrophic phagocytosis, i.e. the internalization of maternal cells and secreted materials, is considered an important function of the trophoblast before the completion of the placenta. Recently, however, unexpected characteristics of the trophoblast have significantly enhanced our understanding of this process. Roles in acquisition of space for embryo development, in tissue remodeling during implantation and placentation and in defense mechanisms are highlighting how this cellular activity may be relevant for the maternal-fetal relationship beyond its nutritional function.
\end{abstract}

KEY WORDS: trophoblast, placenta, phagocytosis, erythrophagocytosis, defense mechanism

\section{Introduction}

Phagocytosis is a specific form of endocytosis involving the engulfment and destruction of extracellular materials, primarily associated with nutrition in unicellular organisms (phagotrophic nutrition) and to innate and adaptive immunity in mammals. In this context, the ability to promptly internalize microorganisms, to either induce or control inflammation and, to activate the adaptive immune response is pivotal to defense mechanisms against a variety of pathogens. Similarly to professional phagocytes (macrophages, dendritic cells and granulocytes) that have phagocytosis as their primary functions, other cells can also phagocytose some particles, as it happens when apoptotic cells are engulfed by a neighbor to maintain the tissue homeostasis.

During early embryogenesis in mammals, the blastocyst differentiation originates the polar and mural trophectoderm, a cellular layer acting as a transducer between maternal and fetal signaling pathways. Among the multiple functions spatial and temporally distributed along gestation, in many species these cells also exhibit phagocytosis. This process is not an exclusive feature of invasive implantations in which maternal material can be de- stroyed or replaced by trophoblastic tissue, but is also observed in epitheliochorial placentas where trophoblast and uterine epithelium cohabit in perfect homeostasis.

The current literature shows different roles played by this trophoblast activity in a number of models and conditions. The main focus of attention is obviously on invasion and nutritional aspects of the trophoblast phagocytosis. However, an overview on trophoblast gene expression throughout pregnancy shows new avenues for phagocytosis contribution to the gestational

\footnotetext{
Abbreviations used in this paper: C3R, component 3 receptor of the complement system; C3b, component 3b of the complement system; FcR, Fc region of immunoglobulin receptor; hFcRn, human neonatal Fcy-receptor; iNOS, inducible nitric oxide synthase; IFN- $\gamma$, interferon-gamma; IGF, insulin growth factor; IL-1, interleukin -1; JAK, Janus tyrosine kinases; MMP, matrix metalloproteinases; NADPH, nicotinamide adenine dinucleotide phosphate; PMA, phorbol myristate acetate; PCNA, proliferating cell nuclear antigen; ROS, reactive oxygen species; STAT, signal transducer and activators of transcription; TLR, toll-like receptor; TNF- $\alpha$, tumor necrosis factor-alpha; TUNEL, terminal transferase-mediated dUTP nick end-labeling.
}

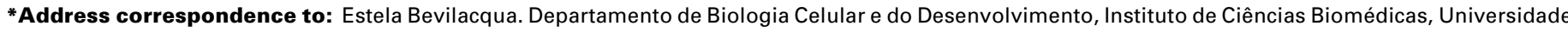
de São Paulo, Av. Prof. Lineu Prestes, 1524 - Butantã, 05508-900 São Paulo, SP Brazil. Fax: +55-11-3091-7307. e-mail: bevilacq@usp.br
} 


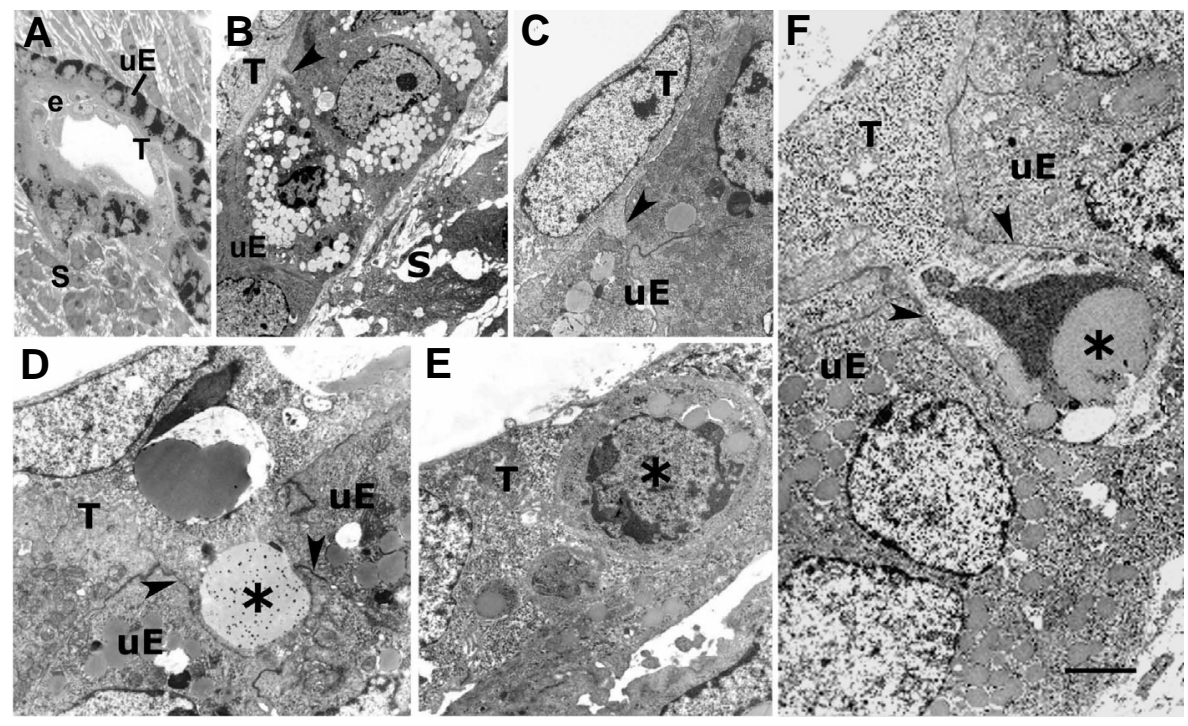

Fig. 1. Mouse implantation site, day $\mathbf{5}$ of gestation. (A) Light microscopy, Toluidine blue staining. The trophoblast (T) is attached to the uterine epithelium (UE). On the left, few cells of the embryoblast can be seen (e). (B-F) Electron micrographs. The figures show a sequence of epithelial uterine (UE) invasion by trophoblast giant cells (T). Arrowheads identify trophoblast projections intruding among epithelial cells and asterisks phagosomes with phagocytosed material. In (E), a whole epithelial cells can be recognized within a trophoblast phagosome. (S) endometrial stroma. Bar in (F) equivalent to: $50 \mu \mathrm{m}(A), 15 \mu \mathrm{m}(B), 5 \mu \mathrm{m}(C), 2 \mu \mathrm{m}(D, F)$ and 1.5 $\mu \mathrm{m}$ in (E).

successful. Here, the phagocytic potential of trophoblast from early to mid-term pregnancy is discussed, highlighting important key aspects of this evolutionarily conserved process.

\section{Endocytosis - phagocytosis before embryo implanta- tion}

Several reports have emphasized the extensive endocytic activity by the embryo at early developmental stages (Enders and Nelson, 1973; Parr and Parr, 1974). This process seems to be closely associated with intake of small particle and fluid for embryo nutrition, but have also been suggested to participate in the embryo attachment to the uterus (Enders, 1976) and transport of crucial survival factors from the mother organism to the embryo, such as insulin and IGF-I insulin growth factor I (Heyner et al., 1989; Smith et al., 1993). Endocytosis of extracellular material requires a receptor-mediated pathway and specific regulatory mechanisms. At the nutritional context, cubilin, a multiligand receptor for vitamin, iron, and protein uptake in adult tissues is thought to account for the protein and cholesterol uptake by the trophectoderm (Assémat et al., 2005). Receptor-mediated endocytosis has also been implicated in uptake of uterine gland secretions by the pig blastocyst trophectoderm (Baumbach et al., 1990). In spite of its importance to the embryo development, little is known concerning the trophectoderm endocytosis and a number of issues remain unsettled.

Phagocytosis of large particles has also been demonstrated at this early stage of embryo development in studies using latex compound $(1-3 \mu \mathrm{m})$ in in vitro conditions (Rassoulzadegan et al., 2000). Although phagocytosis is generally considered a marker for trophoblast differentiation in giant cells during embryo implantation in rodents, it showed to be early preprogrammed at pre- implantation steps in this study. Furthermore, the phagocytic activity of the trophoectoderm obeyed a specific graded pattern, becoming more expressive at the abembryonic than embryonic pole and suggesting a regulatory mechanism controlled by embryoblast signals.

\section{Trophoblast phagocytosis during em- bryo implantation: histotrophic nutri- tion}

As embryo implantation progresses, more evidence of phagocytosis is observed in species in which implantation involves invasion and occupation of uterine territories for further developing of endotheliochorial (in carnivores, for example) or hemochorial placentas (primates and rodents) (Enders and Schlafke, 1969; Knoth and Larsen, 1972; Clint et al., 1979; Hata et al., 1981; Bevilacqua and Abrahamsohn, 1988, 1989; Jones et al., 2001; Enders and Carter, 2006; Enders et al., 2006).

Particularly in rodents, in the course of embryo implantation trophoblast cells acquire a typical phagocytic phenotype, which is expressed in close association with other morphological and biochemical characteristics in consequence of a complex differentiation program, triggered during trophectoderm formation at the morula-blastocyst stage (Red-Horse et al., 2004). In these animals, giant and polyploid cells differentiate from the mural and polar trophectoderm, which constitute the outermost trophoblast layer and exhibit intense phagocytosis and a remarkable ability to invade uterine tissues (Al-Abbass and Schultz, 1966; Gardner, 1975; Bevilacqua and Abrahamsohn, 1988, 1989; Gonçalves et al., 2003; Zybina and Zybina, 2005).

In mice (Enders, 1976; Bevilacqua and Abrahamsohn, 1988, 1989) processes of trophoblast giant cells penetrate through contiguous uterine epithelial cells (Fig. 1), completely embracing and internalizing them. Detached apoptotic epithelial cells are also involved and phagocytosed by trophoblast giant cell processes. After perforating the basal lamina of the uterine epithelium the trophoblast reaches the decidua where it establishes contact with healthy decidual cells and with those showing signs of cellular disorganization. Phagosomes containing decidual cell fragments identify the phagocytic activity of this invasive trophoblast population. Variations in this implantational invasion process occur among the different species; trophoblast is thought to invade either apoptotic epithelial and decidual cells in mice and rats (Welsh and Enders, 1985; Katz and Abrahamsohn, 1987) or healthy cells in cricetid rodents (Parkening, 1976; Ferro et al., 1994), but in all, phagocytosis seems to proceed similarly to eliminate the maternal barriers interposed into its invasion pathway. Likewise normal gestation, the phagocytic activity of trophoblast associated with invasion is also seen in experimentally induced ectopic gestation (Fig. 2, Bevilacqua and Abrahamsohn, 1994). Although this process seems to significantly contribute to acquisition of space for the developing embryo, it is also implicated in providing embryo nutrition (histotrophic nutrition) before 


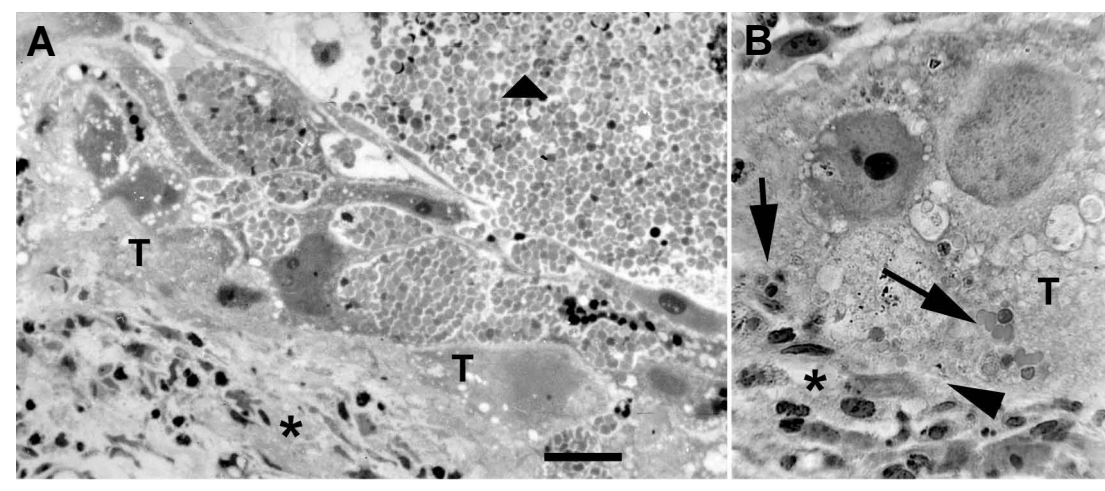

Fig. 2. Ectoplacental cone experimentally transplanted to subcutaneous tissue of female mice. After $96 h$, the explant developed as hemorrhagic nodules associated with intense trophoblast invasion and phagocytosis. (A) The rupture of the host vessels by the invasive trophoblast lead to the formation of blood-containing nodules (triangle) lined by trophoblast giant cell cells (T). (B) At the limit (arrowhead) of the graft with the connective tissue $\left({ }^{*}\right)$, trophoblast cells (T) show phagocytic activity (arrows). Bars: (A) $25 \mu \mathrm{m}$, (B) $15 \mu \mathrm{m}$

placentation is complete (Welsh and Enders, 1985; Bevilacqua and Abrahamsohn, 1989; Enders and Carter, 2006).

However, regardless the invasion degree into the uterus, histotrophic nutrition is a widely spread feature among species (see Enders and Carter, 2006, and references therein), not only as a nutritional source before placentation but also as a complementary uptake of specialized material after placenta development. In many species, it is accomplished by specialized regions for ingestion of uterine secretions, cellular debris and erythrocytes combining endocytic and phagocytic processes. These regions vary from simple areas of uterine glandular secretion ingestion by the trophoblast, as seen in man (Burton et al., 2002) to more specialized structures, as the areolae with significant endocytosis of secretions and the hemophagous areas, with phagocytosis of blood cells. Such structures are seen for instance in the placenta of bitches, in which ingestion of protein occurs in the hemophagous region by phagocytosis and immunoglobulin transfer is peculiar to the labyrinth (Stoffel et al., 2000).

Beyond the limits of the histotrophic nutrition, the phagocytic ability of trophoblast cells throughout the gestation in the different species may be of fundamental importance for the removal of cell debris in the maternal-fetal interface. In this context, the physiological turnover of uterine epithelial cells in the epitheliochorial placenta and of endometrial cells in endotheliochorial and hemochorial placentas could be rapidly assured without trigger- remodeling.

ing an inadequate local inflammatory reaction. In baboon, phagocytic cytotrophoblast cells differentiate between days 23 to 25 of gestation, actively phagocytosing maternal necrotic cells at maternalplacental interface (Jones et al., 2001). In humans necrotic decidual cells was also found in the phagosomal vacuoles within cytotrophoblast cells (Hata et al., 1981). It is also especially relevant in rodents since no other phagocytic cells have been found at the endometrial-trophoblast boundary (Bevilacqua and Abrahamsohn, 1989).

\section{Tissue remodeling}

A role in tissue remodeling during implantation and placentation has also been included as a function of the phagocytosis exhibited by the trophoblast by Manyonda and Choy (1999). The authors show evidences of phagocytosis directed mainly towards extracellular matrix proteins participating of decidual

The proteolysis of matrix components for phagocytosis may be extracellularly mediated by aspartate (cathepsin D), cysteine (cathepsin B, K, L and S) and serine proteases (plasmin, tissue plasminogen activator and urokinase-type plasminogen activator) and matrix metalloproteinases (MMPs).

Human and rodent trophoblast produces MMPs, but this secretion has been chiefly correlated to the trophoblast invasive behavior (Peters et al., 1999; Cohen and Bischof, 2007). In contrast, the expression of cathepsin proteases seems to be associated to the trophoblast differentiation program (Simmons et al., 2007), intracellular breakdown of molecules phagocytosed by trophoblast cells during its invasive activity, and with extracellular digestion of matrix molecules for further phagocytosis (Afonso et al., 1997). As in invasive tumors (Joyce and Hanahan, 2004), trophoblast cells express cathepsins $B, L$, and $D$, capable of digesting matrix molecules including laminin, collagen IV, and fibronectin and of activating the metalloproteinase, stromelysin and pro-urokinasetype plasminogen activator (Murphy et al., 1992; Goretzki et al., 1992; Afonso el al, 1997, Varanou et al., 2006). All of these enzymes related to tissue remodeling have been shown to be produced by mouse trophoblast (Harvey et al., 1995; Alexander etal., 1996; Teesalu etal., 1996). Cathepsin D is immunolocalized in the cytoplasm of trophoblast giant cells and in the extracellular matrix embraced by trophoblast projections likelihood for phago-

Fig. 3. Mouse implantation site, day 7.5 of gestation. The photomicrographs show invasive and phagocytic trophoblast giant cells $(T)$ in contact with decidual cells; frequently this are contain cell debris $\left.{ }^{*}\right)$.(B) A similar region seen in (A) (hematoxylin and eosin stained) where cathepsin D has been immunolocalized. The arrows indicate the contact areas where trophoblast processes are internalizing extracellular matrix and cell debris. Bars in (B) represent $20 \mu \mathrm{m}(\mathrm{A})$ and $40 \mu \mathrm{m}(\mathrm{B})$.
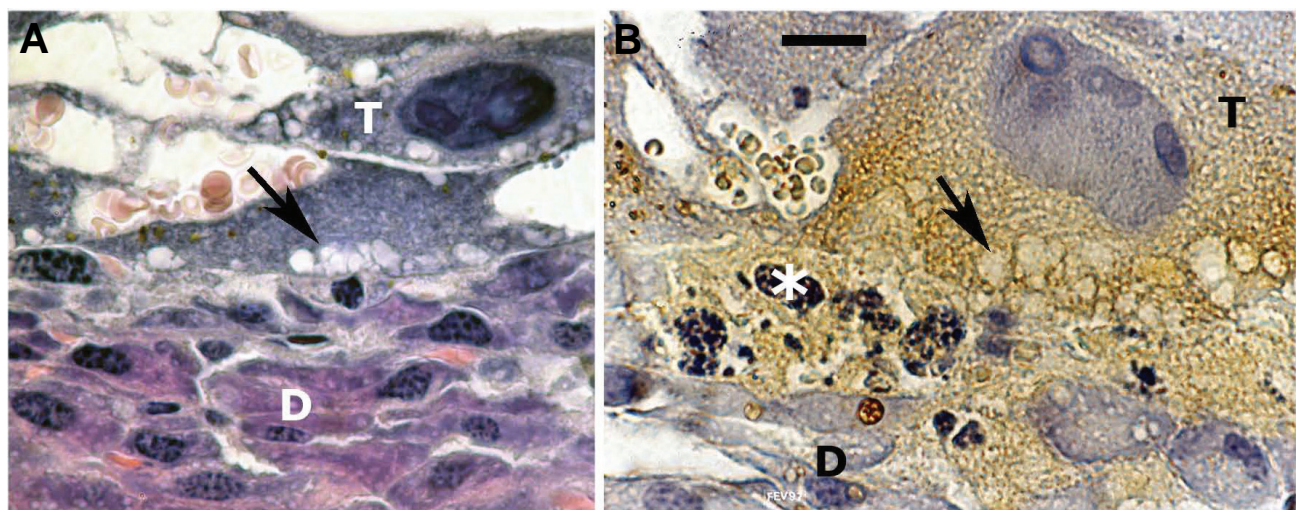
cytic purposes (Fig. 3). More expressive than acid phosphatase activity, cathepsin D seems to be a characteristic of the phagocytosing trophoblast. Biochemical analyses of hemophagous region of the cat placenta, characterized by intense erythrophagocytosis show a low acid phosphatase activity (44\%) and high values in cathepsin D activity (> $300 \%$ ) in relation to the nonphagocytic areas of the placenta (Minazaki et al., 2008). Immunohistochemistry also confirmed these results (Fig. 4). Moreover, experimental induction of low IFN- $\gamma$ profile in pregnant mice females increases immunoreactivity for cathepsin $D$ in trophoblast giant cells and also phagocytic markers such as Lamp-1 and Rab-5 (personal communication).

\section{Erythrophagocytosis}

Very likely, the most notable histotrophic nutrition activity exhibited by trophoblast cells is the phagocytosis of erythrocytes. It evolved in many unrelated groups of Eutherian mammals (Burton, 1982; Enders and Carter, 2006; Mess and Carter, 2006) and has been studied in different species with varied placentation processes (Seal et al., 1972 and references therein). Erythrophagocytosis can be found either in individual cell with phagocytic activity in the trophoblastic layer or in specialized areas, as the hemophagous regions. Erythrocyte internalization is directly related to the protein and iron transfer to the embryo/fetal circulation. Tracing the maternal-fetal iron circuit through Fe-hemoglobin- labeled red cells in different models, Seal and collaborators (1972) showed that transfer of iron to the fetal circulation is temporally faster in absorptive processes in hemochorial placentas than in phagocytosis of extravasated maternal red blood cells within hemophagous organs in epitheliochorial and endotheliochorial placentas. It is important to note that receptor-mediated endocytosis as a biological event is much faster than phagocytosis, which does not invalidate the breakdown of the erythrocyte and release of hemoglobin in trophoblast cells as an effective mechanism.

Histotrophic nutrition and hemophagous organs in different species and in different placental structure have been recently

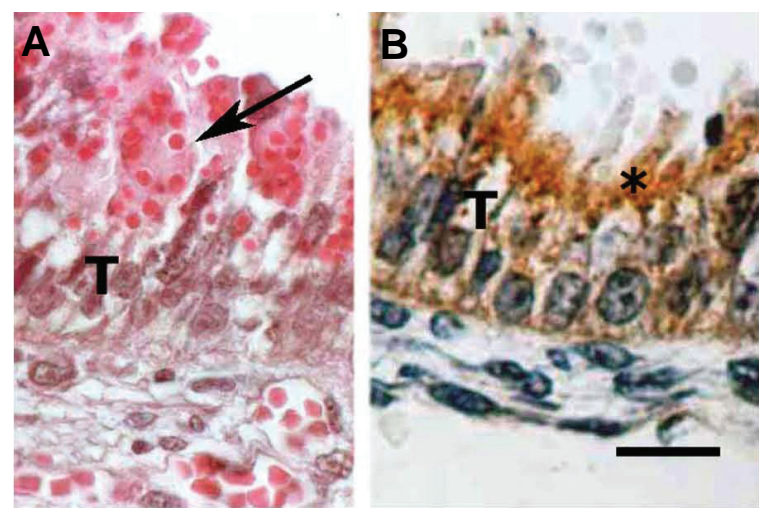

Fig. 4. Hemophagous region of the cat paraplacenta. Very intense erythrophagocytosis is exhibited by cytotrophoblast cells (T). (A) Maternal erythrocytes (arrow) are seen internalized at the trophoblast cytoplasm. (B) Asterisk shows reactive cytotrophoblast cells to cathepsin D (immunohistochemistry, monoclonal anti-human cathepsin D, Dako, USA). Bar in (B) equivalent to $50 \mu \mathrm{m}$ (A) and $40 \mu \mathrm{m}$ (B).

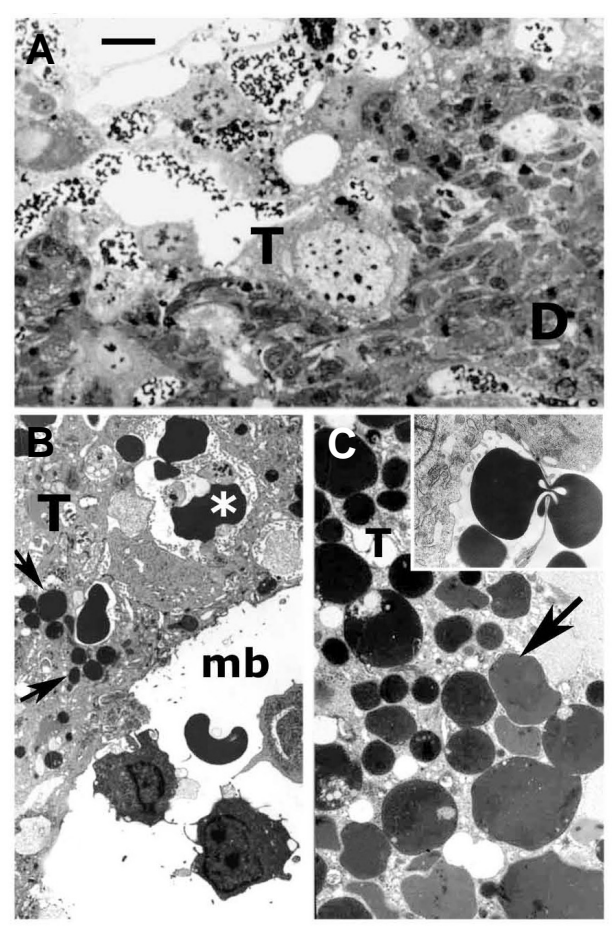

Fig. 5. Calomys callosus (Rodentia, Cricetidae) implantation site: Day 7.5. Erythrophagocytosis by trophoblast giant cells (T). (A) Light microscopy. Maternal blood ( $\mathrm{mb}$ ) is extravasated into the lacunas of the trophoblast network surrounding the embryo. (B,C) Trophoblast giant cell cytoplasm containing erythrophagosomes in different stages of degradation (arrows) and erythrocytes during early phagocytosis steps, adhered to the trophoblast surface (asterisk). The inset shows trophoblast projections surrounding part of an erythrocyte. (D) Decidua. Bar in (A) equivalent to (A) $50 \mu \mathrm{m}$; (B) and inset, $5 \mu \mathrm{m}$ and (C) $2 \mu \mathrm{m}$.

revisited by Enders and Carter (2006). The advantages in having an additional nutritive phagocytic region are emphasized by these authors as highly specialized regions that do not interfere or compete with noble plasma membrane areas working on absorption of several other products.

In the hemochorial placenta of rodents and primates, erythrophagocytosis is an early activity of the invasive trophoblast in individual (rodents and primates) or in syncytial organization (primates). In rodent, erythrophagocytosis is particularly exacerbated during embryo implantation as soon as giant trophoblast cells reach endometrial capillary network, replacing endothelial cells and establishing a direct contact with maternal blood. This activity exhibited by the outermost giant trophoblast layer (Fig. 5) peaks on the first half of gestation when fetal hemopoesis is prominent, decreasing thereafter, when likely iron uptake in labyrinthine hemochorial exchange areas are completely differentiated.

In vitro studies are also consistent with in vivo observations. Human trophoblast cells are able to interiorize and digest erythrocytes, releasing to the culture medium products yielded from this degradation (Contractor and Krakauer, 1976). Choy and Manyonda (1998) showed the capability of the extravillous trophoblast to ingest blood cells, bacteria and fungi particles, but not with the same avidity as seen in professional phagocytes. Mice cultured trophoblast cells also showed lower rates of erythroph- 
agocytosis even when trophoblast were obtained from postimplantation stage, period in which these cells are active phagocytes (Albieri and Bevilacqua, 1996; Albieri et al., 1999, 2005). Regulators of professional phagocytes such as phorbol myristate acetate (PMA), all-trans-retinal and IFN- $\gamma$ however, change this profile and trophoblast giant cells rapidly respond by increasing relevantly the erythrophagocytic rate (Albieri and Bevilacqua, 1996; Albieri et al., 1999, 2005), suggesting that trophoblast phagocytosis is not only a spatially and temporally regulated process but also requires activation by specific regulators. This might explain why under in vitroconditions trophoblast expresses low phagocytic activity, but it also raises the question about which might be the mediators controlling the trophoblast phagocytosis in vivo.

\section{Phagocytosis as a defense mechanism at the maternal fetal interface}

Trophoblast phagocytosis has also been implicated in defense mechanisms. Evidences show that interposed between maternal and fetal organisms, trophoblast may act as a physiological and not only a physical barrier against potentially harmful components present at the maternal-fetal interface. In humans, phagocytosis of cells with atypical tumoral characteristics by syncytiotrophoblast was observed in a woman with acute lymphatic leukemia suggesting a role for trophoblast phagocytosis in preventing transplacental metastasis of leukemic cells (Wang et al., 1983). Phagocytosis by trophoblast in chorioamnionitis has also been indicated as having a key role in the pathogenesis of this infection (Matsubara et al., 2000). During a casual contamination with Candida albicanscultured trophoblast exhibited phagocytic activity and ability to restrict the growth and evolution of the microorganism (Foldes et al., 1973). Although not as efficiently as professional phagocytes Choy and Manyonda (1998) also demonstrated phagocytosis of bacteria and yeast by human trophoblast primary culture. Immunosurveillance at maternal-fetal interface through phagocytosis of immune complexes has also been considered a defense role of the trophoblast phagocytosis (Frauli and Ludwig, 1987).

A number of recent studies examined the mice trophoblast phagocytosis in vivo and in vitro leading to similar results (Schlesinger and Koren, 1967; Delgado and Santos-Buch, 1978; Pavia, 1983; Drake and Rodger, 1987; Albieri et al., 2001; Amarante-Paffaro etal., 2004; Neres etal., 2008). Fetal transmission of Trypanosoma cruzi experimentally infected in pregnant females depended on pathogenicity of the strain and trophoblast phagocytosis. Parasites are observed in the chorionic trophoblast, but in the complete absence of fetal infection (Delgado and Santos-Buch, 1978). Similarly, Neres et al. (2008) found alterations in the mouse placenta after plasmodium infection, but not parasites in the fetal circulation neither positive parasitemia in newborns. This finding points to an efficient placental trophoblastic layer able to block parasite crossing to the fetal blood. The mechanism is not explained by the authors, but phagocytosis stimulated by inflammatory mediators is cogitated as a possibility. In addition, phagocytosis of zymosan particles administered in pregnant female on day 13.5 of gestation can be seen at placental trophoblast giant cells for subsequent 12 hours. In culture, the internalization of these particles was relevantly accelerated and intensified after trophoblast activation by IFN- $\gamma$ (Albieri et al., 2001; Amarante-Paffaro et al., 2004). Furthermore, comparatively to zymosan, Escherichia coliparticles were internalized by placental trophoblast more rapidly, suggesting that phagocytosis may depend on the nature of the target organism and possibly to specific patterns of recognition (Amarante-Paffaro et al., 2004). The mechanism by which trophoblast cells can recognize phagocytic particles remains to be defined. Interestingly, expression of Toll-like receptors (TLR)-2 and 4, which are crucial regulators of the innate immune system by recognizing molecular patterns expressed by microorganisms and by promoting bacterial phagocytosis through induction of a phagocytic gene program (Doyle et al., 2004) was found in the cytotrophoblast and syncytiotrophoblast (Abrahams and Mor, 2005; Ma etal., 2007) and in the mouse placenta (Salminen etal., 2008). Clearly more studies are needed to decipher whether in trophoblast cells TLRs are also involved with acquisition of a phagocytic phenotype and host defense mechanisms.

\section{Mediators of the trophoblast phagocytosis}

\section{Phagocytic receptors}

The events leading to particle engulfment during phagocytosis are, in fact, extremely complex. It starts after adherence of a particle/organism to the phagocyte plasma membrane, step that may be associated with different types of receptors. Among them, are highlighted those for component 3 (C3R) of the complement system, Fc region of immunoglobulins ( $F c R)$, mannose ubiquitously expressed on the surface of pathogens and fibronectin. Phagocytosis can be dramatically enhanced when, under certain circumstances, the particles are coated (opsonized) by the specific ligand of these receptors, i.e.: IgG, C3b, fibronectin or mannose (opsonins) (Swanson and Hoppe 2004).

Important association with selective transfer of maternal IgG across the placenta is attributed to FcR. The localization of IgG and human neonatal $\mathrm{Fc} \gamma$-receptor ( $\mathrm{hFcRn}$ ) in the syncytiotrophoblast suggests that $\mathrm{hFcRn}$ is a relevant mediator of the IgG transcytosis, although part of the internalized IgG is not transferred to the fetal organism, but directed to a degradative pathway, into acidic early endosomes (Fuchs and Ellinger, 2004). The exact mechanisms of the selective and active transfer of IgG across the placental barrier are not fully understood, but there is no doubt that receptors for Fc region of IgGs are important. In this context the role played by FcR-IgG as a scavenger mechanism for clearance of immune complexes at the maternal fetal interface has been left aside.

Complement plays a major role in the defense against microorganisms. The protein C3 of complement complex participates in both, antibody dependent classical and antibody independent alternative pathways (Leslie and Nielsen, 2004). Cleavage of C3 yields biologically active fragments named $\mathrm{C} 3 \mathrm{a}$, a vasoactive peptide and C3b, able to bind to cell surface of foreign particles and mediating phagocytosis. Albieri et al. (1999) evaluated the role of C3b-opsonic phagocytosis as an effector mechanism of the mouse implanting trophoblast. Very low levels of phagocytic activity were seen when the plasma was C3-complement deficient. In contrast, phagocytosis of C3b-bound zymosan was remarkably increased in comparison with zymosan alone. Although C3b-Receptor (also named CR1, it binds to the comple- 
ment proteins $\mathrm{C} 1 \mathrm{q}$ (subunit $\mathrm{C} 1$ of serum complement system), $\mathrm{C} 4 \mathrm{~b}$ (complement component $4 \mathrm{~b}$ ) and $\mathrm{C} 3 \mathrm{~b}$ and it is able to function as opsonins for several microorganisms) has been immunolocalized in cultured trophoblast cells, it is unclear, which are the molecular mechanisms underlying this finding and obviously, more studies are needed to assess the real contribution of $\mathrm{C} 3 \mathrm{bR}$ in the trophoblast phagocytosis.

Specific CR1 binding to their ligands alone does not mediate internalization of a particle without additional signals, but can

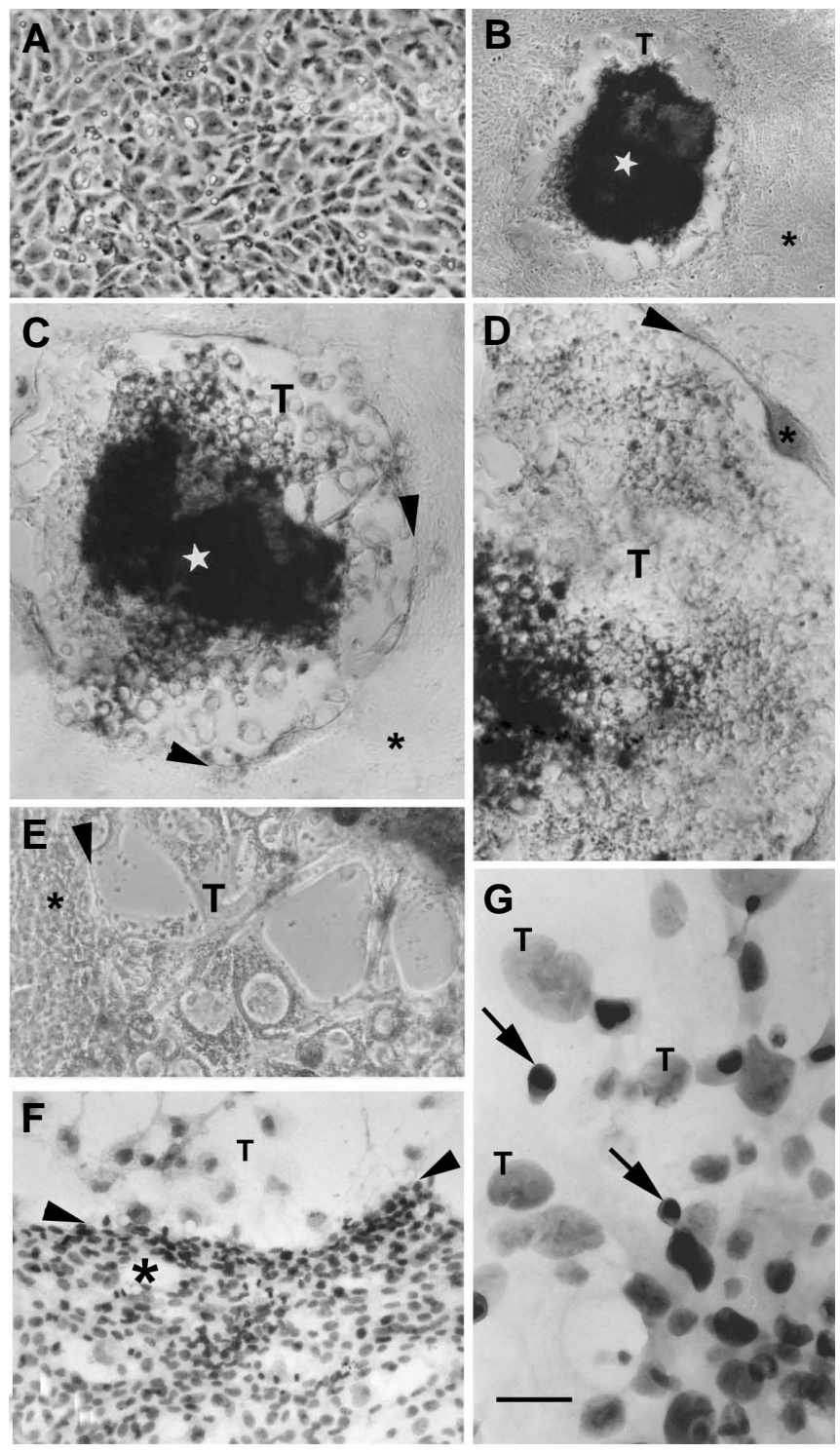

Fig. 6. Co-cultures of A31 mesenchymal cell line and mice ectoplacental cones. (A) Confluent A31-cell line before the introduction of the ectoplacental cones observed at inverted light microscopy (ILM). (B-D) Ectoplacental cone (white star) and A31 cells respectively at 6, 24 and 48 h after co-culturing (ILM). (E,F,G) Details of the trophoblast giant cells (T)A31 cells (asterisks) interface (arrowheads), respectively through ILM and light microscopy in Toluidine blue staining. Arrows identify detached A31 cells over the layer of trophoblast giant cells. These cells show picknotic nuclei and changed shape typically of degenerative cells. The bar in $(G)=250 \mu \mathrm{m}$ in $(A, B, D, F) ; 200 \mu \mathrm{m}$ in (C); $85 \mu \mathrm{m}$ in (E) and $30 \mu \mathrm{m}$ in (G). enhance others receptor-mediated phagocytosis.'/n vitro, this activation signal can be stimulated with phorbol esters (Underhill and Ozinsky, 2002).

Both fibronectin and vitronectin can also play roles as nonspecific opsonins for pathogens and cell debris. Professional phagocytes and nonphagocytic cells can recognize these extracellular matrix components mainly through $\alpha 5 \beta 1$ and $\alpha v \beta 3$ integrins and internalize them. Similarly to complement receptors, a second signal is needed to trigger the particle internalization. The integrins $\alpha v \beta 3$ and the vitronectin-binding integrin, $\alpha v \beta 5$, can also interact with the surface molecule CD36 to mediate phagocytosis of apoptotic cells (Underhill and Ozinsky, 2002 and references therein). In addition, in nonprofessional phagocytes integrinmediated phagocytosis is considered an important mechanism for removal of extracellular matrix components during tissue remodeling or tumor invasion (Lee et al., 1996; Coopman et al., 1998). The expression of these integrins by the extravillous cytotrophoblast has been associated with an invasive phenotype to anchor the embryo to the uterine wall (Burrows et al., 1996), but not in the context of trophoblast phagocytosis, which also can be occurring.

\section{IFN- $\gamma$ induced phagocytosis and nitric oxide production}

Chemical modification of the particles to be phagocytosed is also a remarkable feature of professional phagocytes. It ranges from plasma membrane alteration to cell death induced by cytotoxic highly reactive oxygen species (hydrogen peroxide, active oxygen species, and peroxidase) and nitrogen intermediates (nitric oxide) generated by the oxidative burst. Exposure to IFN$\gamma$ greatly enhances this microbicidal/citotoxic activity of macrophages and induces them to secrete nitric oxide and cytokines such as IL-1, IL-6, IL-8, and TNF- $\alpha$ (Gattoni et al., 2006). Similarly to professional phagocytes, the effect of IFN- $\gamma$ on mice trophoblast cells also is associated with activation of phagocytosis (six-fold increase upon IFN- $\gamma$ exposure, Albieri et al., 2005), nitric oxide production and protein and gene expression of nitric oxide synthase isoforms, including the macrophage, inducible isoform that was specifically stimulated by this cytokine (Gagioti et al., 2000). IFN- $\gamma$-receptor triggers a signaling pathway through Janus tyrosine kinases (JAK) that phosphorylate tyrosine residues of the cytoplasmic domain of the receptor and signal transducer and activators of transcription (STATs). Homodimers of phosphorylated STAT-1 translocate to the nucleus, activating specific gene program IFN- $\gamma$-dependent (Darnell et al., 1994). In support of this and as previously reported in macrophages, IFN- $\gamma$ increases the gene expression of iNOS and STAT- 1 in trophoblast cells, but not of STAT2, related to regulatory pathways other than IFN- $\gamma$ (Leanza et al., 2007). Up-regulation of STAT1 is involved with the intensity of IFN- $\gamma$ responses at inflammatory sites and thereby, considered an additional regulatory mechanism for IFN- $\gamma$-induced responses. In the trophoblast cells it might be a means by which trophoblast cells could extend its phagocytic activity. The interruption of tyrosine kinase R-dependent phosphorylation by staurosporine reduces JAK-STAT gene expression and completely abolishing iNOS expression. Expression of iNOS is essential for control of several experimental infections and might be at least one key to understanding the participation of the trophoblast in preventing transplacental infection of Trypanosoma cruzi or Plasmodium berghei(Delgado and Santos-Buch, 1978; Neres et al., 2008) as 
previously mentioned. IFN- $\gamma$ signal transduction in macrophages also involves TLR 2 (Lafuse et al., 2006; Arko-Mensah et al., 2007; O'Mahony et al., 2008). As recently shown by Salminen et al. (2008) lipopolysaccharides from gram-negative bacteria mostly increased the expressions of TLR and cytokines by uterine and placental cells. Experimental design crossing IFN- $\gamma$ signal transduction, TLR and phagocytosis in trophoblast would be interesting and elucidating.

\section{Reactive oxygen species and trophoblast phagocytosis}

Protective phagocytosis also induces NADPH-oxidase activity, which is the major source of reactive oxygen species (chiefly superoxide anion radical, hydrogen peroxide, hydroxyl radical, singlet oxygen, hypochlorite and indirectly, nitric oxide) in macrophages and neutrophils (Nathan et al., 1983; Babior, 2004). These molecules react with DNA, lipids, carbohydrates and proteins causing severe damage to membranes and organelles, leading to cell senescence and death (Badwey and Karnovsky, 1980). Although not unique in this production, NADPH-oxidase and iNOS are exclusive enzymes specialized in antimicrobial activity and therefore, able to provide essential protection against infection in vivo by killing pathogens (Shiloh et al., 1999). Macrophage deficient in inducible nitric oxide synthase and/or NADPHoxidase revealed that these enzymes are essential for the transcriptional changes associated with macrophage activation. Phagocytosis is not a pre-requisite for reactive oxygen species (ROS) production, since the NADPH oxidase complex may also be activated by varied stimuli, which includes PMA and all-transretinal among several others (Babior, 2004).

In 1995, Gagioti and collaborators estimate the production of ROS by the post-implanting mouse embryo using luminol-sensitized chemiluminescence. The embryos were stimulated with PMA or retinal and reaction kinetics followed over 10 minutes. ROS secretion was directly proportional to the number of embryos and was suppressed at $56 \%$ by superoxide dismutase, $25 \%$ by mannitol and $16 \%$ by catalase, specific scavengers of superoxide anion, hydroxyl radical and hydrogen peroxide, respectively. Embryos deprived of trophoblast showed no light emission, suggesting that the source of ROS generation was in the trophoblast. Recently, the transcription of the NADPH oxidase components in the mouse trophoblast has been deeply studied by Gomes and Bevilacqua (2008). The main components of this enzymatic complex, the membrane gp91phox and p22phox, and the cytosolic p67phox, p40phox, p47phox, and Rac1 were expressed in stimulated and unstimulated trophoblast cells. Assembly of the NADPH oxidase on trophoblast membrane upon stimulated conditions was also analyzed by confocal microscopy and corroborates the phagocyte character of the NADPH-oxidase in trophoblast cells (Rocha et al., 2007; Lorenzon et al., 2008).

The possibility of ROS release into extracellular compartment during phagocytic process has been related to the cytolytic effect exhibited by these molecules and, perhaps by this means, the trophoblast may play active role in the phagocytosis of maternal cells during embryo implantation process and microorganisms at the maternal-placental interface. Welsh and Enders (1991) suggested that the trophoblast might be acting on, inducing or still, accelerating, the uterine cells death process during early stages of implantation. Nevertheless, it is generally accepted that the epithelial and decidual cells regulate the invasiveness of tropho-

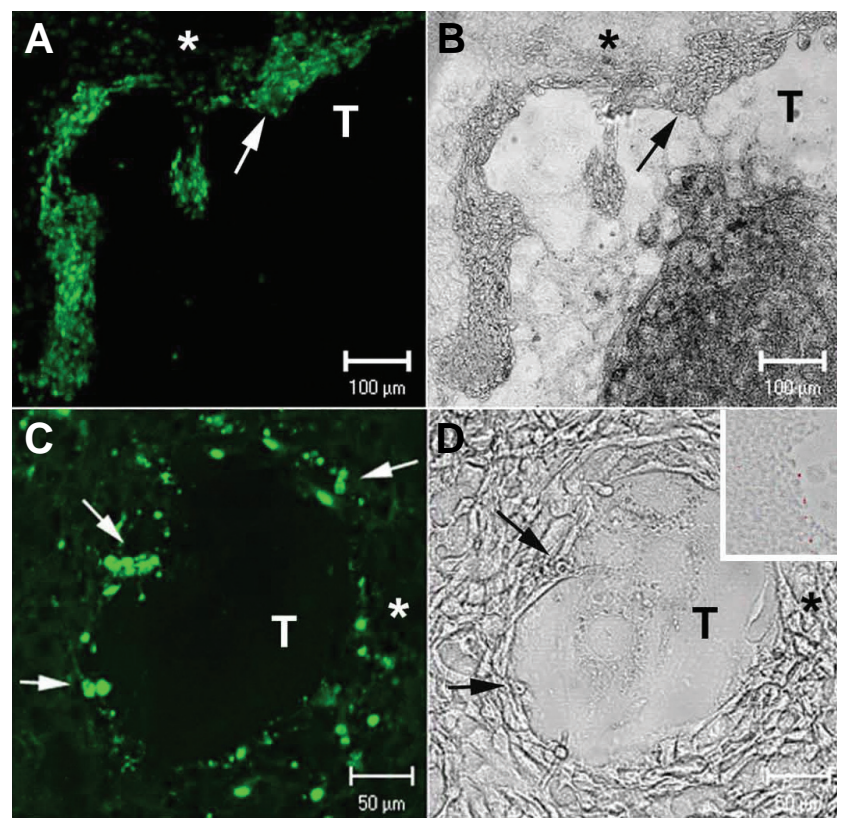

Fig. 7. Co-cultured ectoplacental cones and $\mathbf{A} 31$ cells. Representative confocal microscopy images from $24 h(\mathbf{A}, \mathbf{B})$ and $48 h$ (C,D) co-cultures after 3 min incubation with FITC-albumin ( $3 \mathrm{mg} / \mathrm{mL}$ ) and further washing in PBS. Normasky contrast from the same fluorescence field $(\mathbf{A}, \mathbf{B})$ is shown in (B,D), respectively. Note the $A 31$ labeled cells at the periphery of outgrowth ectoplacental cone (arrows). (C,D) An invasive giant trophoblast cell that lacks continuity with the ectoplacental cone. Label is evident in many cells, demonstrating the permeability of FITC-albumin through the plasma membrane, which does not occur in viable cells. The inset in $(D)$ shows TUNEL reaction in a similar region.

blast cells by programming their cell death. In this context, trophoblast invasiveness would depend on not only of developmental regulatory genes but also of microenvironmental-derived extrinsic signals to express specific molecular repertoire and advance stepwise towards an invasive phenotype. To investigate whether ROS produced by implanting trophoblast might be playing a role in this process, co-cultures of A31 embryonic mesenchymal cell line and ectoplacental cone were performed.

After confluence, these cells still showed high rates of proliferation and very low indices of cell death as indicated by proliferating cell nuclear antigen (PCNA) immunolocalization (5.2\% in sub confluent cultures and $3.8 \%$ in confluent cultures) and Trypan blue exclusion applied directly to the monolayer or terminal transferase-mediated dUTP nick end-labeling (TUNEL) reaction (index of cell death for confluent and subconfluent cultures was $0.05 \%)$.

Ectoplacental cone adhesion to the mesenchymal cells and trophoblast invasion is depicted in the Figure 6 along $72 \mathrm{~h}$ of coculture. On the bordering between the invasive trophoblast and A31 cell monolayer, cells with degenerative characteristics are evident along the time of co-culturing. At this particular region, cells with morphological characteristics of apoptosis and mainly necrosis are seen at light and electron microscopy. Beside the typical nuclear changes, necrosis is characterized by a severe cellular insult with lack of plasma membrane integrity, allowing the diffusion of macromolecules. Based on this, necrosis was determined by using FITC-albumin (Sigma Chemical Co., USA) and 


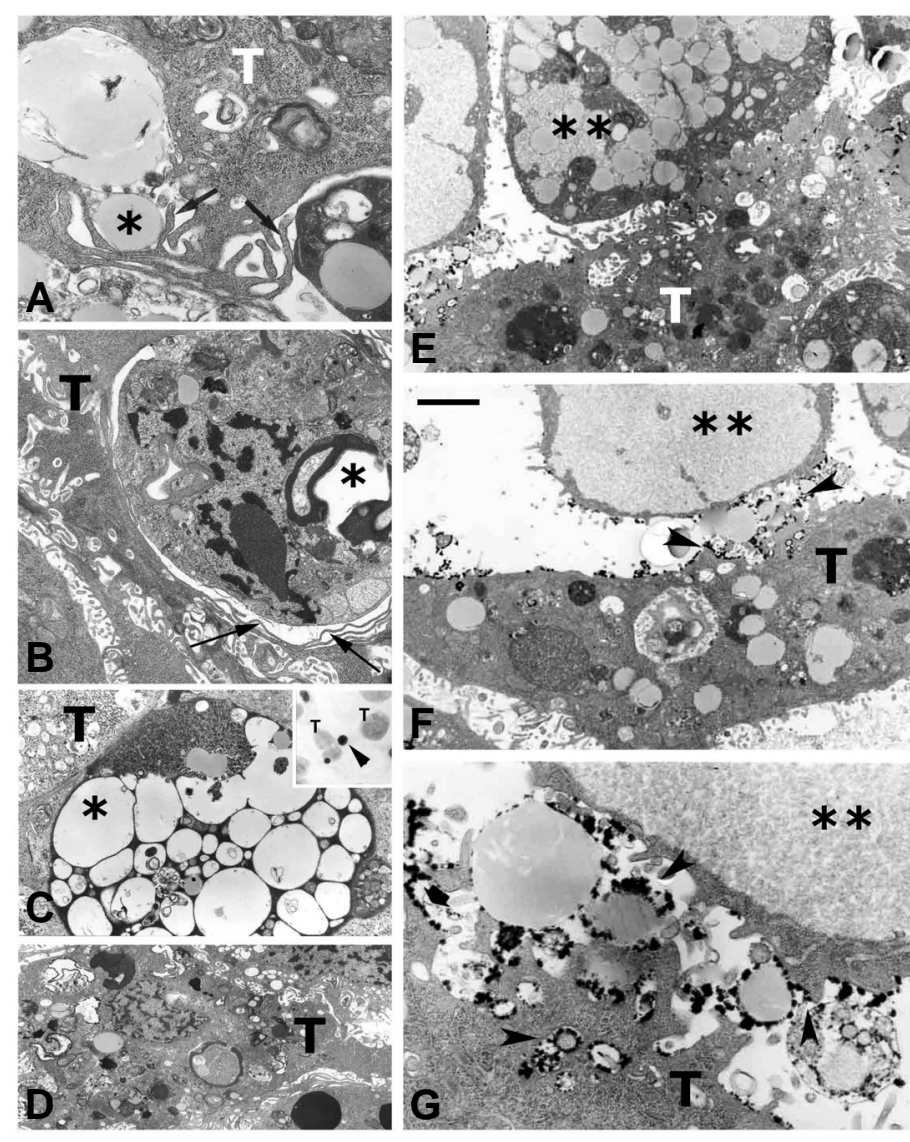

Fig. $8.48 \mathrm{~h}$ co-cultured ectoplacental cones and A31 cells. Electron micrographs. Interface of contact between trophoblast giant cells (T) and A31 cells (**). (A-D) Arrows highlight trophoblast processes surrounding A31 cells. (C) A phagosome $\left({ }^{*}\right)$ containing part of a cell is shown; (D) part of the trophoblast cytoplasm with numerous late phagosomes. (E-G) Briggs reaction (arrowheads) for ultrastructural localization of hydrogen peroxide sites (details of the reaction in Gagioti et al., 1995). Note in $(\mathbf{E}, \mathbf{F})$ that the electrondense precipitated reaction is exclusively found at the trophoblast surface that faces A31 cells and particularly at the contact areas with degenerated cells $\left({ }^{* *}\right)$. (G) Reactive vesicles are also evident in the apical trophoblast cytoplasm. The bar in $(F)$ is equivalent to $2 \mu \mathrm{m}(A), 5 \mu \mathrm{m}(B, C, E, F), 10 \mu \mathrm{m}(D)$ and $80 \mu \mathrm{m}(G)$.

labeled cells were visualized through confocal microscopy (Fig. 7). TUNEL positive staining has been used as an indicator of apoptotic cell death; the indices of apoptosis, however, were always very low $(0.1 \%)$. On contrary, necrosis was a prevalent feature of the cells in contact with the invasive trophoblast (Fig. 7).

Phagocytosis is also intense at the trophoblast-A31 cells interface (Figs. 8 A-D), cytochemical reaction for hydrogen peroxide-producing sites (Brigg's reaction, Briggs, 1975) localized this ROS molecule at the trophoblast surface exclusively at sites in which phagocytosis of degenerative A31 cells were in progress (Figs. 8 E-G).

In this experimental invasion assay not only invasion activity could be followed but also the parallel phagocytic behavior at the growing edge of the trophoblast, which is an additional advantage. Our interpretation to these results leads to the perspective that the release of ROS might determine the capability of trophoblast cells to interfere in vivowith the viability of surrounding cells, being these uterine cells interposed at the invasive pathway either pathogens that have reached the maternal-placental interface by tissue or blood circulation route.

Furthermore, several complications of human pregnancy as preeclampsia for instance, have been associated with an imbalance in both invasive trophoblast activity and placental oxidative metabolism (Myatt and Cui, 2004). Both biological phenomena are closely related to phagocytosis in mice trophoblast. In this point of view, kept the intrinsic differences among the species, perhaps this system can help to understand the changes in the gene program and behavior of the trophoblast concerning invasion and, reactive species production and balance.

\section{Cues from genes}

The extremely fast development of scientific tools in the last years is opening a completely new perspective for the biological understanding of cellular functions. The screening of 1,000 gene expression in post-implantation trophoblast can give us a minimal idea of this universe and challenged to understand the pathways and networks that account for the multiple phagocytic responses. Among 376 genes expressed in trophoblast cells at this period, 124 are direct or indirectly associated to the phagocytic process and other 40 to immune responses in general (Hoshida et al., 2007). Some are closely related to the lysosome structure and function as the lysosomal membrane glycoprotein 1 and 2, cathepsin $D$ and $L$, but, many of them are also associated with phagocytic process and defense mechanisms. For example, we can mention genes involved in integrin-dependent phagocytosis (Cd63, Cd9, Cd81, Cd82 and Cd151) and phagocytic surface receptors ( $C d 68$ and $C d 14$ ), complement system (complement receptor related protein [Crry], complement component $1, \mathrm{q}$ subcomponent binding protein [ $(C 1 q b p)$, among many others. This broad spectrum of gene expressions seems to provide a strong potential for trophoblast cells to participate in particle recognition and phagocytosis and clearly emphasizes its critical role in placental development.

\section{Conclusion}

Phagocytosis is a complex process requiring specific signaling pathways and leading to events as diverse as particle engulfment, microorganisms killing and, production of inflammatory mediators that may modulate the immune response. The consequences of phagocytosis vary, and depend on its purpose: nutritional, remodeling or protective. Trophoblast phagocytosis is of special interest, because it is closely connected to the embryo implantation and placentation process, but moreover, it is a challenge as it apparently integrates different roles. A rapid overview on these roles in different species and some associated signaling molecules has been here described. Key information emerged from these multiple phagocytic activities and responses, but they are in their infancy and thus, certainly there still is a lot for coming.

\section{References}

ABRAHAMS, V.M. and MOR, G. (2005). Toll-like receptors and their role in the trophoblast. Placenta 26: 540-547.

AFONSO, S., ROMAGNANO, L. and BABIARZ, B. (1997). The expression and 
function of cystatin $C$ and cathepsin $B$ and cathepsin $L$ during mouse embryo implantation and placentation. Development 124: 3415-3425.

AL-ABBASS, A.H. and SCHULTZ, R.L. (1966). Phagocytic activity of the rat placenta. J. Anat. 100: 349-359.

ALBIERI, A. and BEVILACQUA, E. (1996). Induction of erythrophagocytic activity in cultured mouse trophoblast cells by phorbol myristate acetate and all-transretinal. Placenta 17: 507-512.

ALBIERI, A., AMARANTE, A.M., GAGIOTI, S. and BEVILACQUA, E. (2001). In vitro behavior of post implanting and placental trophoblast cells during zymosan challenging and interferon-g stimulation. Placenta 22: A11.

ALBIERI, A., HOSHIDA, M.S., GAGIOTI, S.M., LEANZA, E.C., ABRAHAMSOHN, I., CROY, A., ASHKAR, A.A. and BEVILACQUA, E. (2005). Interferon-gamma alters the phagocytic activity of the mouse trophoblast. Reprod. Biol. Endocrinol. 3: 34.

ALBIERI, A., KIPNIS, T. and BEVILACQUA, E. (1999). Possible role of activated complement component $\mathrm{C} 3$ in phagocytic activity exhibited by the mouse trophoblast. Am. J. Reprod. Immunol. 41: 343-352.

ALEXANDER, C. M., HANSEL, E., BEHRENDSTEN, O., FLANDERS, M.L., KISHNANI, N.S., HAWKES, S.P. and WERB, Z. (1996). Expression and function of matrix metalloproteinases and their inhibitors at the maternalembryonic boundary during mouse embryo implantation. Development 122: 1723-1736.

AMARANTE-PAFFARO, A., QUEIROZ, G.S., CORREA, S.T., SPIRA, B., and BEVILACQUA, E. (2004). Phagocytosis as a potential mechanism for microbial defense of mouse placental trophoblast cells. Reproduction 128: 207-218.

ARKO-MENSAH, J., JULIÁN, E., SINGH, M. and FERNÁNDEZ, C. (2007). TLR2 but not TLR4 signalling is critically involved in the inhibition of IFN-gammainduced killing of mycobacteria by murine macrophages. Scand. J. Immunol.65: 148-157.

ASSÉMAT, E., VINOT, S., GOFFLOT, F., LINSEL-NITSCHKE, P., ILLIEN, F. CHTELET, F., VERROUST, P., LOUVET-VALLÉE, S., RINNINGER, F. and KOZYRAKI, R. (2005). Expression and role of cubilin in the internalization of nutrients during the peri-implantation development of the rodent embryo. Biol. Reprod. 72: 1079-1086.

BABIOR, B.M. (2004). NADPH oxidase. Curr. Opin. Immunol. 16: $42-47$.

BADWEY, J.A. and KARNOVSKY, M.L. (1980). Active oxygen species and the functions of phagocytic leukocytes. Ann. Rev. Biochem. 49: 695-726.

BAUMBACH, G.A., BARTLEY, N.G., KATTESH, H.G. and GODKIN, J.D. (1990). Immunolocalization and endocytosis of the uterine secretory protein, uteroferrin, in pre-implantation pig trophectoderm on day 11 of pregnancy. Anat. Embryol. 182: $563-568$.

BEVILACQUA, E. and ABRAHAMSOHN, P.A. (1988). Ultrastructure of trophoblast giant cell transformation during invasive stage of implantation of the mouse embryo. J. Morphol. 198: 341-451.

BEVILACQUA, E. and ABRAHAMSOHN, P.A. (1989) Trophoblast invasion during implantation of the mouse embryo. Arch. Biol. Med. Exp. 22: 107-118.

BEVILACQUA, E. and ABRAHAMSOHN, P.A. (1994) Invasiveness of mouse trophoblastic cells in connective tissue. Acta Anat (Basel), 150: 246-252.

BRIGGS, R.T., KARNOVSKY, M.L. and KARNOVSKY, M.J. (1975). Cytochemical demonstration of hydrogen peroxide in polymorphonuclear leukocyte phagosomes. J. Cell. Biol. 64: 254-260.

BURROWS, T.D.; KING, A. and LOKE, Y.W. (1996). Trophoblast migration during human placental implantation. Human Reprod. Update 2: 307-321.

BURTON, G.J. (1982). Placental uptake of maternal erythrocytes-a comparative survey. Placenta 3: 407-434.

BURTON, G.J., WATSON, A.L., HEMPSTOCK, J., SKEPPER, J.N. and JAUNIAUX E. (2002). Uterine glands provide histiotrophic nutrition for the human fetus during the first trimester of pregnancy. J. Clin. Endocrinol. Metab. 87: 29542959.

CHOY, M.Y. and MANYONDA, I.T. (1998). The phagocytic activity of human first trimester extravillous trophoblast. Hum. Reprod. 13: 2941-2949.

CLINT, J.M., WAKELY, J. and OCKLEFORD, C.D. (1979). Differentiated regions of human placental cell surface associated with attachment of chorionic villi, phagocytosis of maternal erythrocytes and syncytiotrophoblast repair. Proc. $R$. Soc. Lond. B. Biol. Sci. 204: 345-353.
COHEN, M. and BISCHOF, P. (2007). Factors regulating trophoblast invasion. Gynecol. Obstet. Invest. 64: 126-130.

CONTRACTOR, S.F and KRAKAUER, K. (1976). Pinocytosis and intracellular digestion of 125I-labelled haemoglobin by trophoblastic cells in tissue culture in the presence and absence of serum. J. Cell Sci. 21: 595-607.

COOPMAN, P.J., DO, M.T., THOMPSON, E.W. and MUELLER, S.C. (1998). Phagocytosis of cross-linked gelatin matrix by human breast carcinoma cells correlates with their invasive capacity. Clin. Cancer Res. 4: 507-515.

DARNELL, J.E.JR., KERR, I.M. and STARK, G.R. (1994). Jak-STAT pathways and transcriptional activation in response to IFNs and other extracellular signaling proteins. Science 264: 1415-1421.

DELGADO, M.A. and SANTOS-BUCH, C.A. (1978). Transplacental transmission and fetal parasitism of Trypanosoma cruzi in outbread white Swiss mice. $A m$. J. Trop. Med. Hyg. 27: 1108-1115.

DOYLE, S.E., O'CONNELL, R.M., MIRANDA, G.A., VAIDYA, S.A., CHOW, E.K., LIU, P.T., SUZUKI, S., SUZUKI, N., MODLIN, R.L., YEH, W.C., LANE, T.F. and CHENG, G. (2004) Toll-like receptors induce a phagocytic gene program through p38. J. Exp. Med. 199: 81-90

DRAKE, B.L. and RODGER, J.C. (1987). Phagocytic properties of cultured murine trophoblast. Placenta 8: 129-134.

ENDERS, A.C. (1976). Anatomical aspects of implantation. J. Reprod. Fertil. Suppl. 25: 1-15.

ENDERS, A.C. and CARTER, A.M. (2006). Comparative placentation: some interesting modifications for histotrophic nutrition - A Review. Placenta 27 Suppl A: S11-S16

ENDERS, A.C. and NELSON, D.M. (1973). Pinocytotic activity of the uterus of the rat. Am. J. Anat. 138: 277-299.

ENDERS, A.C. and SCHLAFKE, S. (1969). Cytological aspects of trophoblastuterine interaction in early implantation. Am. J. Anat. 125: 1-29.

ENDERS, A.C., BLANKENSHIP, T.N., CONLEY, A.J. and JONES, C.J. (2006) Structure of the midterm placenta of the spotted hyena, Crocuta crocuta, with emphasis on the diverse hemophagous regions. Cells Tissues Organs 183 141-155.

FERRO, E.A.V. and BEVILACQUA, E. (1994) Trophoblastic invasion of the uterine epithelium in Calomys callosus (Rodentia, Cricetidae). J. Morph. 221: 139-152.

FOLDES, J.J., SCHWARTZ, J. and KEHATY, T. (1973). Trophoblast and phagocytosis. I. In vitro phagocytosis by human cultured trophoblasts. Int. J. Fertil. 20: 228-230

FRAULI M. and LUDWIG H. (1987). Demonstration of the ability of Hofbauer cells to phagocytose exogenous antibodies. Eur. J. Obstet. Gynecol. Reprod. Biol. 26: $135-144$

FUCHS, R. and ELLINGER, I. (2004). Endocytic and transcytotic processes in villous syncytiotrophoblast: role in nutrient transport to the human fetus. Traffic 5: 725-738.

GAGIOTI, S., COLEPICOLO, P. and BEVILACQUA, E. (1995). Post-implantation mouse embryos have the capability to generate and release reactive oxygen species. Reprod. Fertil. Dev. 7: 1111-1116.

GAGIOTI, S., SCAVONE, C. and BEVILACQUA, E. (2000). Participation of the mouse implanting trophoblast in nitric oxide production during pregnancy. Biol. Reprod. 62: 260-268.

GARDNER, R.L. (1975). Analysis of determination and differentiation in the early mammalian embryo using intra- and interspecific chimeras. Symp. Soc. Dev. Biol. 33: 207-236

GATTONI, A., PARLATO, A., VANGIERI, B., BRESCIANI, M. and DERNA, R (2006). Interferon-gamma: biologic functions and HCV terapy (type I/II) (2 of 2 parts). Clin Ter. 157: 457-468.

GOMES, S.Z. and BEVILACQUA, E. (2008). NAD(P)H-oxidase expression in trophoblast cells. Placenta 29: 114.

GONÇALVES, C.R., ANTONIN, S.I., VIANNA-MORGANTE, A.M., MACHADOSANTELLI, G.M. and BEVILACQUA, E. (2003). Developmental changes in the ploidy of mouse implanting trophoblast cells in vitro. Histochem. Cell Biol., 119: 189-198

GORETZSKI, L., SCHMITT, M., MANN, K., CALVETE, J., CHUCHOLOWSKI, N., KRAMER, M., GUNZLER, W., JANICKE, F. and GRAEFF, H. (1992). Effective activation of the proenzyme form of the urokinase-type plasminogen activator 
(prouPA) by the cysteine protease cathepsin L. FEBS Lett. 297: 112-118.

HARVEY, M.B., LECO, K.J., ARCELLANA-PANLILIO, M. Y., ZHANG, X., EDWARDS, D.R. and SCHULTZ, G.A. (1995). Proteinase expression in early mouse embryos is regulated by leukemia inhibitory factor and epidermal growth factor. Development 121: 1005-1014.

HATA, T., OHKAWA, K., TOMITA, M., and KISHINO, M. (1981). Phagocytosis of human cytotrophoblast cell invading into decidual tissue in early stage of gestation. Acta Obstet Gynaecol Jpn. 33: 537-544.

HEYNER, S., RAO, L.V., JARETT, L. and SMITH, R.M. (1989). Preimplantation mouse embryos internalize maternal insulin via receptor-mediated endocytosis: Pattern of uptake and functional correlations. Dev. Biol. 134: 48-58.

HOSHIDA, M.S., GORJÃO, R., LIMA, C., CURI, R., DAHER, S. and BEVILACQUA, E. (2007). Regulation of gene expression in mouse trophoblast cells by interferon-gamma. Placenta 28: 1059-1072.

HUBRECHT, A.A.W. (1889). Studies in mammalian embryology. I. The placentation of Erinaceus europaeus, with remarks on the phylogeny of the placenta. $Q$ $J$ Microsc Sci30: 283-404.

JONES, C.J.P., ENDERS, A.C. and FAZLEABAS. A.T. (2001). Early implantation events in the baboon (Papio anubis) with special reference to the establishment of anchoring villi. Placenta 22: 440-456.

JOYCE, J.A. and HANAHAN, D. (2004). Multiple roles for cysteine cathepsins in cancer. Cell Cycle 3: 1516-1619.

KATZ, S. and ABRAHAMSOHN, P.A. (1987). Involution of the antimesometrial deciduas in the mouse (an ultrastructural study). Anat. Embryol. 176: 251-258.

KNOTH, M and LARSEN, JF. (1972). Ultrastructure of a human implantation site. Acta Obstet. Gynecol. Scand. 51: 385-393.

LAFUSE, W.P., ALVAREZ, G.R., CURRY, H.M. and ZWILLING, B.S. (2006). Mycobacterium tuberculosis and Mycobacterium avium inhibit IFN-gammainduced gene expression by TLR2-dependent and independent pathways. $J$ Interferon Cytokine Res. 26: 548-561.

LEANZA, E.C., HOSHIDA, M.S., COSTA, A.F., FERNANDES, C.M., TEIXEIRA C.F.P. and BEVILACQUA, E. (2007). Signaling molecules involved in IFNgamma-inducible nitric oxide synthase expression in the mouse trophoblast. Am. J. Reprod. Immunol. 58: 537-546.

LEE, W., SODEK, J. and MCCULLOCH, C.A. (1996). Role of integrins in regulation of collagen phagocytosis by human fibroblasts. J. Cell Physiol. 168: 695-704.

LESLIE, R.G. and NIELSEN, C.H. (2004). The classical and alternative pathways of complement activation play distinct roles in spontaneous $\mathrm{C} 3$ fragment deposition and membrane attack complex (MAC) formation on human B lymphocytes. Immunology 111: 86-90.

LORENZON, A.R., ROCHA, C.R.R., VIEIRA, J.S., GOMES, S.Z. and BEVILACQUA E. (2008). Activation of $\mathrm{NAD}(\mathrm{P}) \mathrm{H}$-oxidase and xanthine-oxidase and trophoblast reactive oxygen species production. Placenta 29: 115.

MA, Y., KRIKUN, G., ABRAHAMS, V.M., MOR, G., and GULLER S. (2007). Cell type-specific expression and function of toll-like receptors 2 and 4 in human placenta: implications in fetal infection. Placenta 28: 1024-1031.

MANYONDA, I.T. and CHOY, M.Y. (1999). Collagen phagocytosis by human extravillous trophoblast: potential role in trophoblastic invasion. J. Soc. Gynecol. Investig. 6: 158-166.

MATSUBARA, S., TAKIZAWA, T., YAMADA, T., MINAKAMI, H. and SATO, I. (2000). Phagocytosis of chorion laeve trophoblasts in patients with chorioamnionitis-associated preterm delivery: ultrastructural and enzyme-histochemical observations. Placenta 21: 273-279.

MESS, A. and CARTER, A.M. (2006). Evolutionary transformations of fetal membrane characters in Eutheria with special reference to Afrotheria. J. Exp. Zoolog. B. Mol. Dev. Evol. 306: 140-163.

MINAZAKI, C.K., GAGIOTI, S., ZAGO, D., TERRA, W., ARAUJO, V.C., OLIVEIRA, R.A. and BEVILACQUA, E. (2008). Acid phosphatase and cathepsin D are active expressed enzymes in the placenta of the cat. Res. Vet. Sci. 84: 326-334.

MURPHY, G., WARD, R., GAVRILOVIC, J. and ATKINSON S. (1992). Physiological mechanisms for metalloproteinase activation. Matrix Supp/1: 224-230.

MYATT, L and CUI, X. (2004). Oxidative stress in the placenta. Histochem. Cell Biol. 122: 369-382.

NATHAN, C.F., MURRAY, H.W., WIEBE, M.E., and RUBIN, B.Y. (1983). Identification of interferon- as the lymphokine that activates human macrophage oxidative metabolism and antimicrobial activity. J. Exp. Med. 158: 670-689

NERES, R., MARINHO, C.R.F., GONÇALVES, L.A., CATARINO, M.B. and PENHAGONÇALVES, C. (2008). Pregnancy outcome and placenta pathology in Plasmodium berghei ANKA infected mice reproduce the pathogenesis of severe malaria in pregnant women. PLOS ONE3: e1608.

O'MAHONY, D.S., PHAM, U., IYER, R., HAWN, T.R. and LILES, W.C. (2008). Differential constitutive and cytokine-modulated expression of human Toll-like receptors in primary neutrophils, monocytes, and macrophages. Int. J. Med. SCi. 5:1-8.

PARKENING, T.A. (1976). An ultrastructural study of implantation in the golden hamster. II. Trophobalstic invasion and removal of the uterine epithelium. $J$. Anat. 122: 211-230.

PARR, M.B. and PARR, E.L. (1974). Uterine luminal epithelium: protrusions mediate endocytosis, not apocrine secretion, in the rat. Biol. Reprod. 11: 220233.

PAVIA, C.S. (1983). Expression of the cell-mediated antimicrobial immunity by mouse trophoblast monolayers. J. Infect. Dis. 147: 1006-1010.

PETERS, T.J., ALBIERI, A., BEVILACQUA, E., CHAPMAN, B.M., CRANE, L.H., HAMLIN, G.P., SEIKI, M. and SOARES, M.J. (1999). Differentiation-dependent expression of gelatinase B/matrix metalloproteinase- 9 in trophoblast cells. Cell Tissue Res. 295: 287-296.

RASSOULZADEGAN, M., ROSEN, B.S., GILLOT, I. and CUZIN, F. (2000). Phagocytosis reveals a reversible differentiated state early in the development of the mouse embryo. EMBO J. 19: 3295-3303.

RED-HORSE, K., ZHOU, Y., GENBACEV, O., PRAKOBPHOL, A., FOULK, R., MCMASTER, M. and FISHER, S.J. (2004). Trophoblast differentiation during embryo implantation and formation of the maternal-fetal interface. J. Clin. Invest. 114: 744-754.

ROCHA, C.R., LORENZON, A.R., VIEIRA, J.S., GOMES, S.Z. and BEVILACQUA E. (2007). superoxide anion production by trophoblast cells. Placenta 28: A.10.

SALMINEN, A., PAANANEN, R., VUOLTEENAHO, R., METSOLA, J., OJANIEMI, M., AUTIO-HARMAINEN, H. and HALLMAN, M. (2008). Maternal endotoxininduced preterm birth in mice: fetal responses in toll-like receptors, collectins, and cytokines. Pediatr Res. 63: 280-286.

SCHLESINGER, M. and KOREN, Z. (1967). Mouse trophoblast cells in tissue culture. Fertil. Steril. 18: 95-101.

SEAL., U.S., SINHA, A.A. and DOE, R.P. (1972). Placental iron transfer: relationship to placental anatomy and phylogeny of the mammals. Am. J. Anat. 134: 263-269.

SHILOH, M.U., MACMICKING, J.D., NICHOLSON, S., BRAUSE, J.E., POTTER, S., MARINO, M., FANG, F., DINAUER, M., and NATHAN, C. (1999). Phenotype of mice and macrophages deficient in both phagocyte oxidase and inducible nitric oxide synthase. Immunity 10: 29-38.

SIMMONS, D.G., FORTIER, A.L. and CROSS, J.C. (2007). Diverse subtypes and developmental origins of trophoblast giant cells in the mouse placenta. Dev Biol 304: 567-578.

SMITH, R.M., GARSIDE, W.T., AGHAYAN, M., SHI, C.Z., SHAH, N., JARETT, L. and HEYNER, S. (1993). Mouse preimplantation embryos exhibit receptormediated binding and transcytosis of maternal insulin-like growth factor I. Biol. Reprod. 49: 1-12.

STOFFEL, M.H., FRIESS, A.E. and HARTMANN, S.H. (2000). Ultrastructural evidence of transplacental transport of immunoglobulin $\mathrm{G}$ in bitches. J. Reprod. Fertil. 188: 315-326.

SWANSON, J.A. and HOPPE, A.D. (2004). The coordination of signaling during FC receptor-mediated phagocytosis. J. Leukoc. Biol. 76: 1093-1103.

TEESALU, T., BLASI, F. and TALARICO, D. (1996). Embryo implantation in mouse: fetomaternal coordination in the pattern of expression of UPA, UPAR, PAI-1 and alpha 2MR/LRP genes. Mech. Dev. 56: 103-116.

UNDERHILL, D.M. and OZINSKY, A. (2002). Phagocytosis of microbes: Complexity in Action. Annu. Rev. Immunol. 20: 825-852.

VARANOU, A., WITHINGTON, S.L., LAKASING, L., WILLIAMSON, C., BURTON, G.J. and HEMBERGER, M. (2006). The importance of cysteine cathepsin proteases for placental development. J. Mo./Med. 84: 305-317.

WANG, T., HAMANN, W. and HARTGE, R. (1983). Strucutural aspects of a placenta from a case of maternal acute lymphatic leukaemia. Placenta 4: 185- 
195.

WELSH, A.O. and ENDERS, A.C. (1985). Light and electron microscopic examination of the mature decidual cells of the rat with emphasis on the antimesometrial deciduas and its degeneration. Am. J. Anat. 172: 1-30.

WELSH, A.O. and ENDERS, A.C. (1991). Chorioallantoic placenta formation in the rat: I. Luminal epithelial cell death and extracellular matrix modifications in the mesometrial region of implantation chambers. Am. J. Anat. 192: 215-231.

ZYBINA, T.G. and ZYBINA, E.V. (2005). Cell reproduction and genome multiplication in the proliferative and invasive trophoblast cell populations of mammalian placenta. Cell Biol. Int. 29: 1071-1083.

\section{Further Related Reading, published previously in the Int. J. Dev. Biol.}

See our recent Special Issue Epigenetics \& Development edited by Saadi Khochbin and Stefan Nonchev at: http://www.ijdb.ehu.es/web/contents.php?vol=53\&issue=2-3

See Special Issue Pattern Formation edited by Michael K. Richardson and Cheng-Ming Chuong at: http://www.ijdb.ehu.es/web/contents.php?vol=53\&issue=5-6

The influence of the intrauterine environment on human placental development Graham J. Burton, Eric Jauniaux and D. Stephen Charnock-Jones Int. J. Dev. Biol. (2010) 54: 303-312 (doi: 10.1387/ijdb.082764gb)

Spatiotemporal expression of the selenoprotein $\mathbf{P}$ genein postimplantational mouse embryos

Se-Ra Lee, Jung-Min Yon, In-Jeoung Baek, Mi-Ra Kim, Chun-Gui Park, Beom-Jun Lee, Young-Won Yun and Sang-Yoon Nam

Int. J. Dev. Biol. (2008) 52: 1005-1011

A simple in vivo approach to investigate invasive trophoblast cells Juan A. Arroyo, Toshihiro Konno, Darya C. Khalili and Michael J. Soares Int. J. Dev. Biol. (2005) 49: 977-980

Involvement of the proto-oncogene c-ets 1 and the urokinase plasminogen activator during mouse implantation and placentation.

D Grevin, J H Chen, M B Raes, D Stehelin, B Vandenbunder and X Desbiens Int. J. Dev. Biol. (1993) 37: 519-529

Immunoregulatory factors contributing to fetal allograft survival. D Rukavina, M Kapovic and A Radojcic

Int. J. Dev. Biol. (1991) 35: 275-278
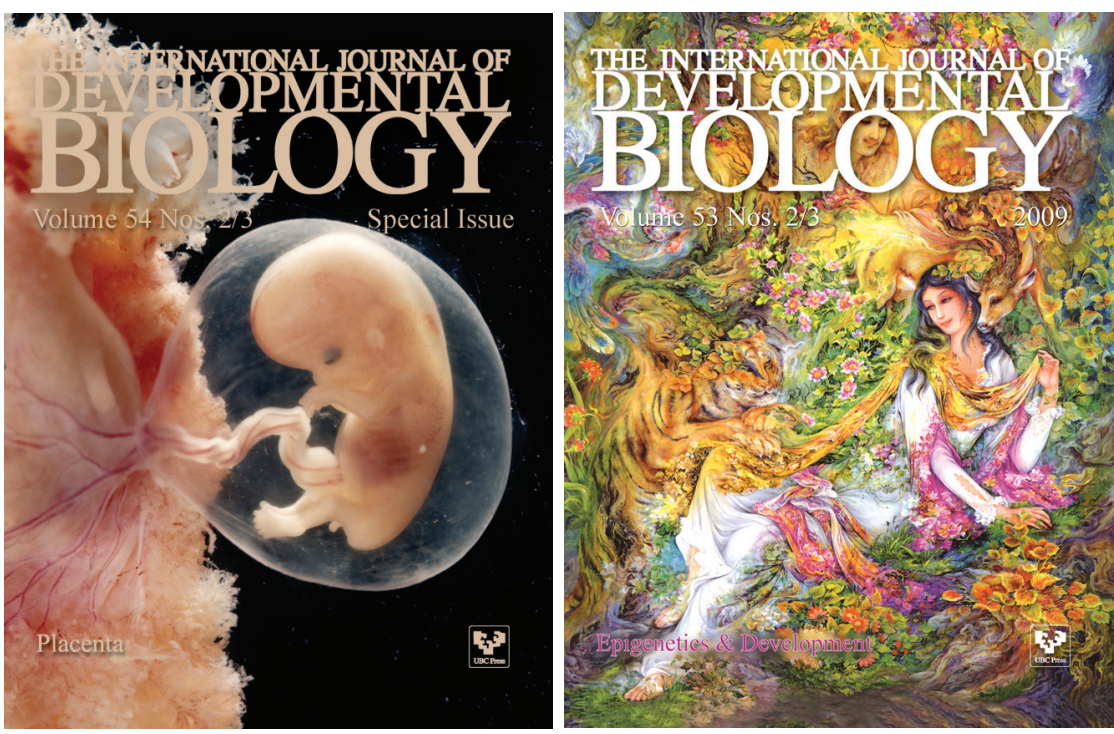

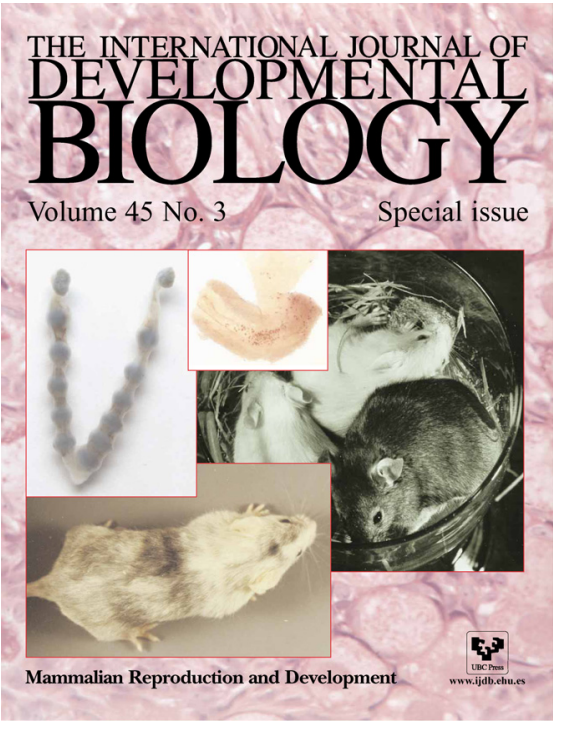

5 yr ISI Impact Factor $(2008)=3.271$

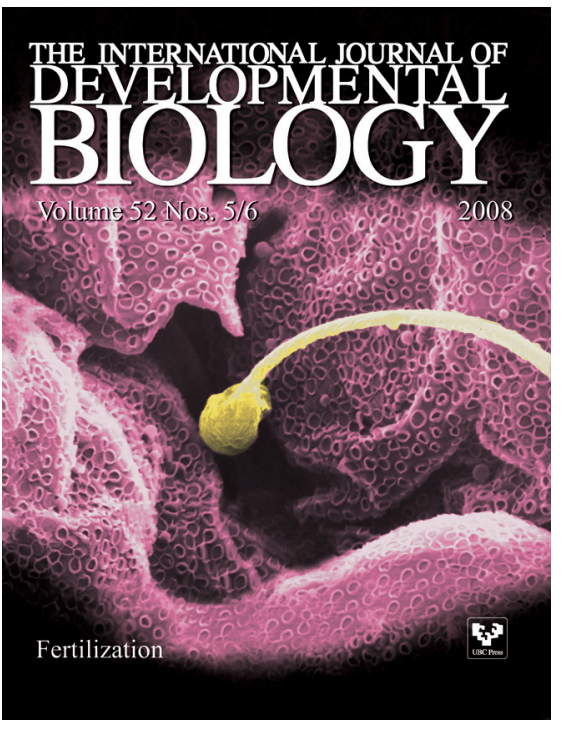

